\title{
First serological record of Coxiella burnetii infection in the equine population of Slovakia
}

\author{
Monika Drážovská $^{1} \cdot$ Marián Prokeš $^{1}$ (D) • Boris Vojtek ${ }^{1} \cdot$ Jana Mojžišová $^{1} \cdot$ Anna Ondrejková $^{1} \cdot$ Luboš Korytár $^{1}$
}

Received: 30 April 2021 / Accepted: 13 August 2021 / Published online: 22 October 2021

(C) The Author(s) 2021

\begin{abstract}
Coxiella burnetii is a worldwide zoonotic pathogen causing $\mathrm{Q}$ fever in various animal species and humans. In Slovakia, cases of C. burnetii infection in both animals and humans are confirmed every year. The role of horses in the epidemiology of this neglected disease is still unclear. In our study, we focused on a serosurvey of $C$. burnetii in the equine population in Slovakia by the ELISA method. Subsequently, a nested PCR was performed to detect the 16S rRNA fragment of the genus Coxiella. Among 184 horse sera, the presence of specific antibodies to C. burnetii was detected in four samples, representing a $2.17 \%$ seropositivity. All the positive horses were mares; two originated from Central Slovakia and two from Eastern Slovakia. Although the number of positive samples was too small for a determination of statistical significance, our results provide the first confirmation of antibodies to C. burnetii in horses from Slovakia. Although no positive PCR result was obtained, these serological findings may help to clarify the circulation of the pathogen in the environment.
\end{abstract}

Keywords Coxiella burnetii $\cdot$ ELISA $\cdot$ Horse $\cdot$ Q fever $\cdot$ Serology $\cdot$ Zoonosis

\section{Introduction}

Q fever is a worldwide spread zoonotic disease associated with severe illness in humans and animals. Coxiella burnetii (Derrick, 1939) is a bacterium that can infect a wide range of animals, e.g. sheep, goats, cattle, dogs, cats, horses, birds, rodents, and ticks. The infected animals shed $C$. burnetii in their birth products, faeces, milk, and urine. However, the circulation dynamics of $C$. burnetii in and through horses is still unclear. The natural reservoir of C. burnetii encompasses many free-living vertebrates, but the major risk of infecting humans arises through contact with infected ruminant livestock and their contaminated products, mainly through the inhalation of contaminated aerosols of birth fluids either from abortions or from normal parturitions (Aitken 1989; Honarmand 2012; Roest et al. 2013a; Aljafar et al. 2020; Khademi et al. 2020; Abdel-Moein and Zaher 2021). The

Marián Prokeš

marian.prokes@uvlf.sk

1 Department of Epizootiology, Parasitology and Protection of One Health, University of Veterinary Medicine and Pharmacy in Košice, Komenského 73, 04181 Košice, Slovak Republic organism leads an obligate intracellular life cycle, during which it multiplies in the phagolytic compartments of the phagocytic cells in the host s immune system. This characteristic makes studying the organism particularly difficult, and it is perhaps one of the reasons why much still remains unknown about the organism and its pathogenesis (Bewley 2013). Coxiella burnetii is frequently detected in ticks and laboratory experiments have revealed that at least some tick species are competent vectors. Coxiella burnetii has been considered to be the only species of the Coxiella genus. However, there is evidence that Coxiella-like (CL) organisms have a high homology with the pathogenic C. burnetii, based on the $16 \mathrm{~S}$ rRNA sequence phylogenetic analyses (Gottlieb et al. 2015; Trinachartvanit et al. 2018), and they are widespread in ticks (Rahal et al. 2020; Chisu et al. 2021). In Slovakia, nonpathogenic CL microorganisms have been registered in ticks (Špitalská et al. 2018). Although some CL endosymbionts of ticks may not play any role in inducing pathology, the possibility of a CL microorganism transformation leading to the emergence of Q fever has been noted (Duron et al. 2015a). Thus, ticks may represent potential sources of $Q$ fever infection for humans and animals (Knap et al. 2019). In Slovakia, the presence of C. burnetii was previously described in Ixodes ricinus (Linnaeus, 1758), Dermacentor reticulatus (Fabricius, 1794), Dermacentor marginatus (Sulzer, 1776), 
Haemaphysalis concinna (Koch, 1844), and Haemaphysalis

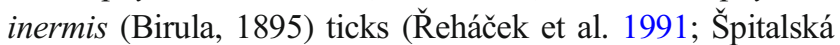
and Kocianová 2003; Špitalská et al. 2018). Slovakia is a country with a dense tick population due to a high abundance of various biotopes for ticks, which range from meadows and forests of the Pannonian lowlands to the Carpathian woods. The diversity of habitats and a wide range of vertebrate hosts (birds, small mammals, deer and wild boar) create suitable conditions for the survival of ticks (Kocianová et al. 2008). An infection caused by C. burnetii is often difficult to identify due to its inapparent course, but abortions and infertility have been described in horses (Marenzoni et al. 2013). Stillbirths and neonatal mortality were also recorded in horses in association with C. burnetii(Acland 1993).

The aim of our study was to confirm the circulation of the neglected pathogen, C. burnetii, in the equine population of Slovakia using a serological analysis and a subsequent PCR detection.

\section{Material and methods}

\section{Sample collection}

A total of 184 healthy horses (97 mares, 21 stallions and 66 geldings) from the Western, Central and Eastern regions of Slovakia were investigated (Table 1). Blood, with and without anticoagulants, was collected from the jugular vein in the period from April 2018 to October 2020 for PCR and serological analyses. The samples were obtained from 16 various, randomly-selected locations in Slovakia (Fig. 1).

\section{Serological analysis}

The presence of IgG antibodies to $C$. burnetii in the serum samples was investigated by the ELISA method using the ID Screen Q Fever Indirect Multi-species Kit (IDvet, Montpellier, France). The procedure was performed according to the manufacturer's instructions. The results were expressed as an optical density ratio of the sample to the positive control $(\mathrm{S} / \mathrm{P})$ based on the following calculation:

$\mathrm{S} / \mathrm{P}(\%)=\frac{(\text { OD sample }- \text { OD negative control })}{(\text { OD positive control }- \text { OD negative control })} \times 100$

The samples with a S/P less than $40 \%$ were determined to be negative, and for the purpose of the present study, doubtful samples ( $\mathrm{S} / \mathrm{P}$ values between $40 \%$ and $50 \%$ ) were considered negative; while the samples with a $\mathrm{S} / \mathrm{P}$ value more than $50 \%$ were evaluated as positive.

\section{DNA isolation and PCR analysis}

Genomic DNA was isolated from whole blood using the DNeasy Blood and Tissue Kit (Qiagen, Hilden, Germany) according to the manufacturer's instructions. The isolated DNA was stored at $-20^{\circ} \mathrm{C}$ until it was used.

The 16S rRNA gene of the Coxiella genus was amplified by a modified nested PCR, as described by Seo et al. (2016). The first round of the PCR was performed using specific primers Cox16S-F1 (5'-CGTAGGAATCTACC TTRTAGWGG-3') and Cox16S-R (5'-GCCTACCC GCTTCTGTACAATT-3') with an amplicon size of 1321-1429 bp. For the second round, the primers Cox16S-F2 (5'-TGAGAACTAGCTGTTGGRRAGT-3') and Cox $16 \mathrm{~S}-\mathrm{R}$ were used for the amplification of the
Table 1 Occurrence of $\mathrm{IgG}$ antibodies to Coxiella burnetii in horses by their age, sex, and origin

\begin{tabular}{|c|c|c|c|c|c|c|}
\hline \multirow[t]{2}{*}{ Location } & \multirow[t]{2}{*}{ Sex } & \multicolumn{2}{|c|}{ Age $\leq 10$ years } & \multicolumn{2}{|c|}{ Age $>10$ years } & \multirow[t]{2}{*}{ Total } \\
\hline & & positive & negative & positive & negative & \\
\hline \multirow{3}{*}{$\begin{array}{l}\text { Western Slovakia } \\
(n=43)\end{array}$} & mares & - & 9 & - & 13 & 22 \\
\hline & geldings & - & 10 & - & 11 & 21 \\
\hline & stallions & - & - & - & - & 0 \\
\hline \multirow{3}{*}{$\begin{array}{l}\text { Central Slovakia } \\
(n=64)\end{array}$} & mares & 1 & 21 & 1 & 16 & 39 \\
\hline & geldings & - & 6 & - & 11 & 17 \\
\hline & stallions & - & 5 & - & 3 & 8 \\
\hline \multirow{3}{*}{$\begin{array}{l}\text { Eastern Slovakia } \\
(n=77)\end{array}$} & mares & - & 11 & 2 & 23 & 36 \\
\hline & geldings & - & 11 & - & 17 & 28 \\
\hline & stallions & - & 7 & - & 6 & 13 \\
\hline \multirow{3}{*}{$\begin{array}{l}\text { Total } \\
(n=184)\end{array}$} & mares & 1 & 41 & 3 & 52 & 97 \\
\hline & geldings & 0 & 26 & 0 & 40 & 66 \\
\hline & stallions & 0 & 12 & 0 & 9 & 21 \\
\hline
\end{tabular}




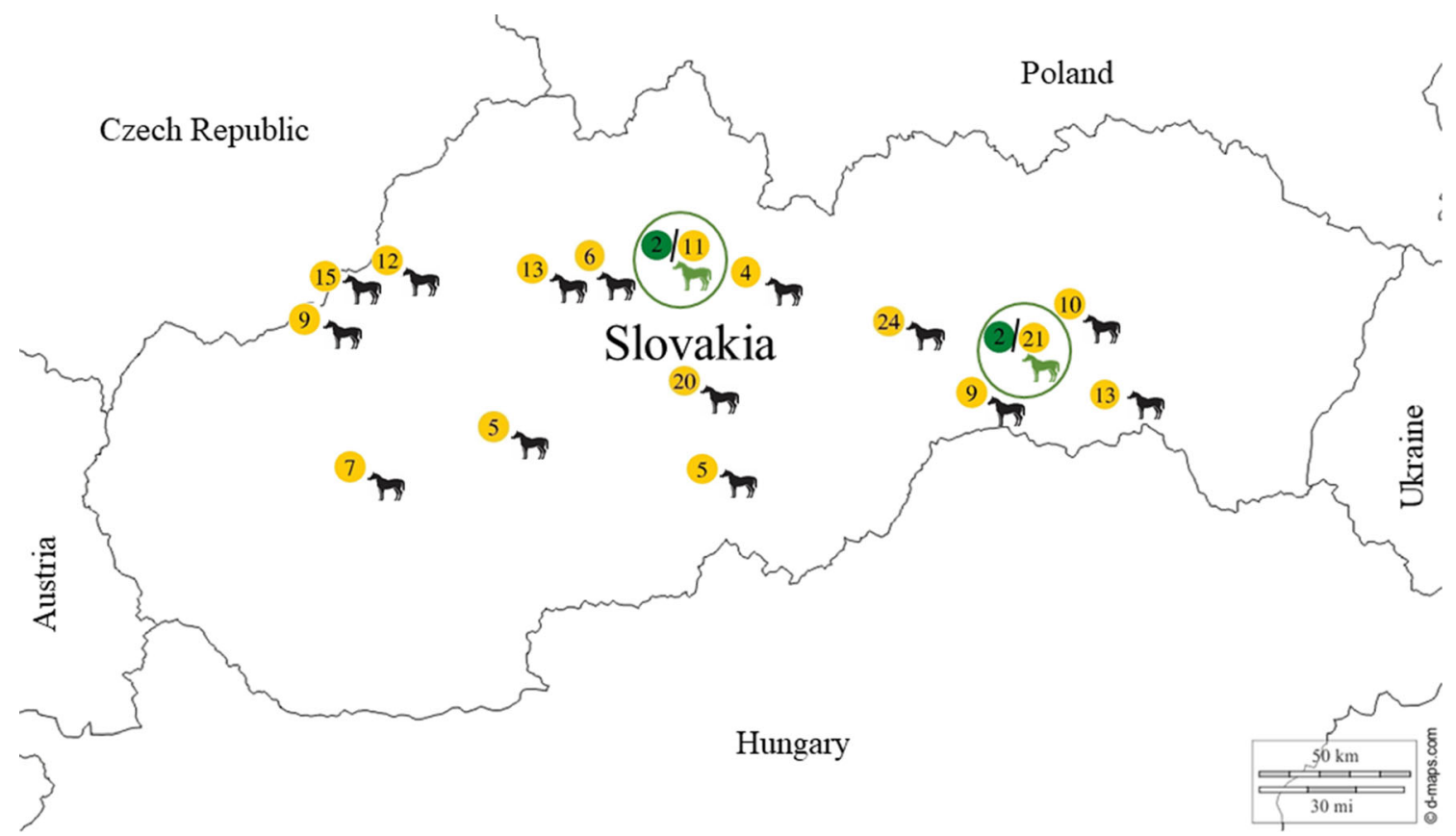

Fig. 1 Sampling locations; number of horses coming from Slovakia; the green colour represents the occurrence of seropositive horses and yellow colour represents the total number of sampled horses in the stables

719-826 bp fragments. The PCR reaction was performed using the Biometra TOne $96 \mathrm{G}$ thermocycler (Analytik Jena, Jena, Germany), in the following steps: predenaturation cycle at $93{ }^{\circ} \mathrm{C}$ for $3 \mathrm{~min}$, followed by $35 \mathrm{cy}$ cles, each consisting of a denaturation at $93{ }^{\circ} \mathrm{C}$ for $30 \mathrm{~s}$, annealing at $56{ }^{\circ} \mathrm{C}$ for $30 \mathrm{~s}$, and an extension at $72{ }^{\circ} \mathrm{C}$ for $1 \mathrm{~min}$, ending with a final extension at $72{ }^{\circ} \mathrm{C}$ for $5 \mathrm{~min}$. The PCR products were visualised on $1.5 \%$ agarose gel with a Gel Red Nucleic Acid Stain (Biotinum, Fremont, USA).

\section{Results}

Our results (Table 1) confirmed a $2.17 \%$ seroprevalence of antibodies to C. burnetii in the horses in Slovakia. All of the horses were without any clinical symptoms of $\mathrm{Q}$ fever at the sampling time, as well as three months earlier. However, tick bites had been noted on all the horses by their owners in the past. Specific IgG antibodies were detected in four mares. One animal belonged to the age group ,younger than or equal to 10 years" and three mares were ,older than 10 years". In association with the localisation, we confirmed two positive cases at the same stable in Central Slovakia, and two positive cases, also at the same stable, in Eastern Slovakia. No statistical analysis was performed, as the size of the positive sample was too small. No blood sample was PCR positive for the $16 \mathrm{~S}$ rRNA of the Coxiella genus.

\section{Discussion}

The results summarised in this study represent the first information about the prevalence of IgG antibodies to $C$. burnetii in the sera of horses bred in the territory of Slovakia. Out of 184 examined horses, four $(2.17 \%)$ animals were seropositive. All of the positive samples originated from mares. Three seropositive mares were older than 10 years. To date, the presence of $C$. burnetii in Slovakia has been reported in different

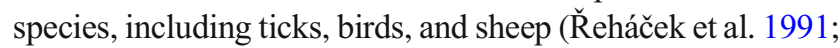
Špitalská and Kocianová 2003; Dorko et al. 2010; Berthová et al. 2016). The presence of antibodies to $C$. burnetii has also been confirmed in the captive breeding of wild animals, such as mouflons, goats, sheep and fallow deer kept at ZOO Košice (Dorko et al. 2009). Human cases of Q fever are reported in Slovakia where the notification rate in humans was 0.02 per 100,000 in 2019 , and 0.04 per 100,000 population in 2018 (one case in 2019, two cases in 2018; and no human case was reported in 2015-2017) (EFSA and ECDC 2019, 2021). In Slovakia, a $4.07 \%$ seroprevalence of antibodies to $C$. burnetii in cattle was also reported (MARDSR 2019).

The particular role of horses as reservoirs of $C$. burnetii in Slovakia has not yet been determined. However, there are indications that horses may play an important role in the spread of Q fever as reservoirs for $C$. burnetii(Khademi et al. 2020). Seo et al. (2016) described antibodies to C. burnetii in the horses of South Korea. They identified 11 samples out of 816 horses $(1.3 \%)$ as being seropositive for C. burnetii by ELISA. Also, Desjardins et al. (2018) described antibodies to $C$. burnetii in the horse sera in endemic areas of 
Southeast France, in Camargue (west of the mouth of the Rhône River) and on the Plain of La Crau (east of the mouth of the Rhône River). They confirmed a 4\% and 12\% seroprevalence in 2015 and 2016, respectively. Furthermore, they confirmed an association between the locations with seropositive horses and those where Q-fever-related human cases were previously described. Li et al. (2020) confirmed by PCR the presence of $C$. burnetii in $39.5 \%$ of the investigated horses in China. Unlike these researchers, in our study we failed to detect and molecularly characterise the pathogen in horses. The PCR negativity may have been due to the fact that the horses did not suffer from an acute infection at the time of the sampling. However, the seropositivity of some animals indicates previous contact with the pathogen or even a past infection.

Some literary sources report clinical Q fever cases in a community of horseback riders or people visiting horse facilities (Nett et al. 2012; Roest et al. 2013b). In addition to direct contact with infected horses, ticks infesting horses may also represent a risk factor in the $\mathrm{Q}$ fever transmission (Roest et al. 2013b; Duron et al. 2015b; Desjardins et al. 2018). The presence of $C$. burnetii was detected in aborted equine placentas and foetuses (Leon et al. 2012; Runge et al. 2012). All the seropositive horses examined in the present study were mares, but the history of abortions in these animals is not known. Although no transmission of infections from horses to humans has been reported, studies have hypothesised that some individuals, such as equine veterinarians or breeders, could potentially be at a higher risk of infection (Karagiannis et al. 2009; Palmela et al. 2012; Van den Brom et al. 2013; Sun et al. 2016; Akter et al. 2020).

Until now, only limited facts about the epidemiology of C. burnetii in horses has been available. Marenzoni et al. (2013) indicated a possible role of horses as sources of the pathogen for other animal species, as well as humans. Similarly, Roest et al. (2013b) and Seo et al. (2016) stated that horses are probably the reservoirs of $C$. burnetii for other susceptible organisms. Our serological survey provides the first evidence to date of seropositivity to $C$. burnetii in the horse population of Slovakia. This could be the basis for further research on this neglected, but serious vector-borne zoonosis.

Funding This publication is the result of the implementation of the project: „Open scientific community for modern interdisciplinary research in medicine (OPENMED)", ITMS2014+: 313011 V455 supported by the Operational Programme Integrated Infrastructure, funded by the ERDF. This work was financially supported by the KEGA Project No. 014UVLF-4/2019 granted by the Ministry of Education, Science, Research and Sport of the Slovak Republic and by the Project No. APVV-19-0440 of the Slovak Research and Development Agency.

\section{Declarations}

Ethic statement The study was performed according to the guidelines of The Ethics Committee of the University of Veterinary Medicine and
Pharmacy in Košice. All animal samples examined in this study were collected by veterinarians upon the consents of the animal owners.

Conflict of interest There is no conflict of interest.

Open Access This article is licensed under a Creative Commons Attribution 4.0 International License, which permits use, sharing, adaptation, distribution and reproduction in any medium or format, as long as you give appropriate credit to the original author(s) and the source, provide a link to the Creative Commons licence, and indicate if changes were made. The images or other third party material in this article are included in the article's Creative Commons licence, unless indicated otherwise in a credit line to the material. If material is not included in the article's Creative Commons licence and your intended use is not permitted by statutory regulation or exceeds the permitted use, you will need to obtain permission directly from the copyright holder. To view a copy of this licence, visit http://creativecommons.org/licenses/by/4.0/.

\section{References}

Abdel-Moein KA, Zaher HM (2021) Parturient cat as a potential reservoir for Coxiella burnetii: a hidden threat to pet owners. Vector Borne Zoonot Dis 21:264-268. https://doi.org/10.1089/vbz.2020.2714

Acland HM (1993) Abortion in mares. In: McKinnon AO, Voss JL (eds) Equine, reproduction. Lea \& Febiger, Philadelphia, pp 554-562

Aitken ID (1989) Clinical aspects and prevention of Q fever in animals. Eur J Epidemiol 5:420-424. https://doi.org/10.1007/BF00140132

Akter R, Legione A, Sansom FM, El-Hage CM, Hartley CA, Gilkerson JR et al (2020) Detection of Coxiella burnetii and equine herpesvirus 1, but not Leptospira spp. or toxoplasma gondii, in cases of equine abortion in Australia - a 25 year retrospective study. PLoS One 15:e0233100. https://doi.org/10.1371/journal.pone.0233100

Aljafar A, Salem M, Housawi F, Zaghawa A, Hegazy Y (2020) Seroprevalence and risk factors of Q-fever (C. burnetii infection) among ruminants reared in the eastern region of the Kingdom of Saudi Arabia. Trop Anim Health Prod 52:2631-2638. https://doi. org/10.1007/s11250-020-02295-6

Berthová L, Slobodník V, Slobodník R, Olekšák M, Sekeyová Z, Svitálková $Z$ et al (2016) The natural infection of birds and ticks feeding on birds with Rickettsia spp. and Coxiella burnetii in Slovakia. Exp Appl Acarol 68:299-314. https://doi.org/10.1007/ s10493-015-9975-3

Bewley KR (2013) Animal models of Q fever (Coxiella burnetii). Comp Med 63:469-476

Chisu V, Mura L, Foxi C, Masala G (2021)Coxiellaceae in ticks from human, domestic and wild hosts from Sardinia, Italy: high diversity of Coxiella-like endosymbionts. Acta Parasitol 66:654-663. https:// doi.org/10.1007/s11686-020-00324-w

Desjardins I, Joulié A, Pradier S, Lecollinet S, Beck C, Vial L et al (2018) Seroprevalence of horses to Coxiella burnetii in an Q fever endemic area. Vet Microbiol 215:49-56. https://doi.org/10.1016/j.vetmic. 2017.11.012

Dorko E, Rimarová K, Pilipčinec E, Trávniček M (2009) Prevalence of Coxiella burnetii antibodies in wild ruminants in Kavecany zoo, Kosice, eastern Slovakia. Ann Agric Environ Med 16:321-324

Dorko E, Pilipčinec E, Rimárová K, Kostovčíková J (2010) Serological study of Q fever in sheep in the territory of eastern Slovakia. Ann Agric Environ Med 17:323-325

Duron O, Noël V, McCoy KD, Bonazzi M, Sidi-Boumedine K, Morel O (2015a) The recent evolution of a maternally-inherited endosymbiont of ticks led to the emergence of the Q fever pathogen, Coxiella 
burnetii. PLoS Pathog 11:e1004892. https://doi.org/10.1371/ journal.ppat.1004892

Duron O, Sidi-Boumedine K, Rousset E, Moutailler S, Jourdain E (2015b) The importance of ticks in Q fever transmission: what has (and has not) been demonstrated? Trends Parasitol 31:536-552. https://doi.org/10.1016/j.pt.2015.06.014

EFSA and ECDC (2019) The European Union one health 2018 Zoonoses report. EFSA J 17:e05926. https://doi.org/10.2903/j.efsa.2019.5926

EFSA and ECDC (2021) The European Union one health 2019 Zoonoses report. EFSA J 19:e06406. https://doi.org/10.2903/j.efsa.2021.6406

Gottlieb Y, Lalzar I, Klasson L (2015) Distinctive genome reduction rates revealed by genomic analyses of two Coxiella-like endosymbionts in ticks. Genome Biol Evol 7:1779-1796. https://doi.org/10.1093/ gbe/evv108

Honarmand H (2012) Q fever: an old but still a poorly understood disease. Interdiscip Persp Inf Dis 2012:131932. https://doi.org/10. $1155 / 2012 / 131932$

Karagiannis I, Schimmer B, Van Lier A, Timen A, Schneeberger P, Van Rotterdam B et al (2009) Investigation of a Q fever outbreak in a rural area of the Netherlands. Epidemiol Infect 137:1283-1294. https://doi.org/10.1017/S0950268808001908

Khademi P, Ownagh A, Ataei B, Kazemnia A, Eydi J, Khalili M et al (2020) Molecular detection of Coxiella burnetii in horse sera in Iran. Comp Immunol Microbiol Infect Dis 72:101521. https://doi.org/10. 1016/j.cimid.2020.101521

Knap N, Žele D, Glinšek Biškup U, Avšič-Županc T, Vengušt G (2019) The prevalence of Coxiella burnetii in ticks and animals in Slovenia. BMC Vet Res 15:368. https://doi.org/10.1186/s12917-019-2130-3

Kocianová E, Blaškovič D, Smetanová K, Schwarzová K, Boldiš V, Koštanová $Z$ et al (2008) Comparison of an oligo-chip based assay with PCR method to measure the prevalence of tick-borne pathogenic bacteria in Central Slovakia. Biologia (Bratisl) 63:34-37. https://doi.org/10.2478/s11756-008-0007-1

Leon A, Richard E, Fortier C, Laugier C, Fortier G, Pronost S (2012) Molecular detection of Coxiella burnetii and Neospora caninum in equine aborted foetuses and neonates. Prev Vet Med 104:179-183. https://doi.org/10.1016/j.prevetmed.2011.11.001

Li J, Li Y, Moumouni P, Lee SH, Galon EM, Tumwebaze MA et al (2020) First description of Coxiella burnetii and Rickettsia spp. infection and molecular detection of piroplasma co-infecting horses in Xinjiang Uygur autonomous region, China. Parasitol Int 76:102028. https://doi.org/10.1016/j.parint.2019.102028

MARDSR - Ministry of Agriculture and Rural Development of the Slovak Republic (2019) Summary Report of Zoonoses Alimentary and Water Borne Infections in the Slovak Republic in 2019, 25 pp. Available: https://www.mpsr.sk/sprava-o-zoonozachalimentarnych-nakazach-a-nakazach-z-vody-v-slovenskejrepublike-za-rok-2019/506-111-506-16111/. Accessed 10 May 2021

Marenzoni ML, Stefanetti V, Papa P, Casagrande Proietti P, Bietta A, Coletti M et al (2013) Is the horse a reservoir or an indicator of Coxiella burnetii infection? Systematic review and biomolecular investigation. Vet Microbiol 167:662-669. https://doi.org/10.1016/ j.vetmic.2013.09.027

Nett RJ, Book E, Anderson AD (2012) Q fever with unusual exposure history: a classic presentation of a commonly misdiagnosed disease.
Case Rep Infect Dis 2012:916142. https://doi.org/10.1155/2012/ 916142

Palmela C, Badura R, Valadas E (2012) Acute Q fever in Portugal. Epidemiological and clinical features of 32 hospitalized patients. Germs 2:43-59. https://doi.org/10.11599/germs.2012.1013

Rahal M, Medkour H, Diarra AZ, Bitam I, Parola P, Mediannikov O (2020) Molecular identification and evaluation of Coxiella-like endosymbionts genetic diversity carried by cattle ticks in Algeria. Ticks Tick Borne Dis 11:101493. https://doi.org/10.1016/j.ttbdis. 2020.101493

Řeháček J, Úrvölgyi J, Kocianová E, Sekeyová Z, Vavreková M, Kováčová E (1991) Extensive examination of different tick species for infestation with Coxiella burnetii in Slovakia. Eur J Epidemiol 7: 299-303. https://doi.org/10.1007/BF00145682

Roest HI, Bossers A, van Zijderveld FG, Rebel JM (2013a) Clinical microbiology of Coxiella burnetii and relevant aspects for the diagnosis and control of the zoonotic disease Q fever. Vet Q 33:148160. https://doi.org/10.1080/01652176.2013.843809

Roest HI, van Solt CB, Tilburg JJ, Klaassen CH, Hovius EK, Roest FT et al (2013b) Search for possible additional reservoirs for human Q fever, the Netherlands. Emerg Infect Dis 19:834-835. https://doi. org/10.3201/eid1905.121489

Runge M, Hilbert A, Henning K (2012) Contribution to the occurrence of Coxiella burnetii-infection in horses. Prakt Tierarzt 93:220-222

Seo MG, Lee SH, VanBik D, Ouh IO, Yun SH, Choi E et al (2016) Detection and genotyping of Coxiella burnetii and Coxiella-like bacteria in horses in South Korea. PLoS One 11:e0156710. https:// doi.org/10.1371/journal.pone.0156710

Špitalská E, Kocianová E (2003) Detection of Coxiella burnetii in ticks collected in Slovakia and Hungary. Eur J Epidemiol 18:263-266. https://doi.org/10.1023/A:1023330222657

Špitalská E, Sparagano O, Stanko M, Schwarzová K, Špitalský Z, Škultéty L' et al (2018) Diversity of Coxiella-like and Francisellalike endosymbionts, and Rickettsia spp., Coxiella burnetii as pathogens in the tick populations of Slovakia, Central Europe. Ticks Tick Borne Dis 9:1207-1211. https://doi.org/10.1016/j.ttbdis.2018.05. 002

Sun WW, Cong W, Li MH, Wang CF, Shan XF, Qian AD (2016)Coxiella burnetii seroprevalence and risk factors in cattle farmers and farm residents in three northeastern provinces and inner Mongolia autonomous region, China. Biomed Res Int 2016: 7059196. https://doi.org/10.1155/2016/7059196

Trinachartvanit W, Maneewong S, Kaenkan W, Usananan P, Baimai V, Ahantarig A (2018). Coxiella-like bacteria in fowl ticks from Thailand. Parasit Vectors 11:670. https://doi.org/10.1186/s13071018-3259-9

Van den Brom R, Schimmer B, Schneeberger PM, Swart WA, van der Hoek W, Vellema P (2013) Seroepidemiological survey for Coxiella burnetii antibodies and associated risk factors in Dutch livestock veterinarians. PLoS One 8:e54021. https://doi.org/10.1371/journal. pone.0054021

Publisher's note Springer Nature remains neutral with regard to jurisdictional claims in published maps and institutional affiliations. 